\title{
Częstość i obraz kliniczny hypolaktazji u dzieci, młodzieży i studentów ze Szczecina*
}

\section{Frequency and clinical overview of hypolactasia among children, adolescents and students of Szczecin schools}

\author{
Agata Marasz \\ Zakład Pediatrii i Pielęgniarstwa Pediatrycznego Wydziału Nauk o Zdrowiu Pomorskiego Uniwersytetu Medycznego w Szczecinie \\ ul. Żołnierska 48, 71-210 Szczecin \\ Kierownik: dr hab. n. med. Grażyna Czaja-Bulsa
}

\begin{abstract}
SUMMARY
Introduction: Adult type hypolactasia is the most common non allergic abnormal reaction to food. Its frequency increases with age. Hypolactasia creates the risk of decreased milk consumption, which could be the cause of lowered bone density, osteoporosis and fractures.

The aim of the research was to estimate the frequency of hypolactasia among Szczecin's citizens.

Material and methods: 200 randomly chosen people aged between 10-23, divided into three groups: 10-14 years old (36 children), 15-19 years old (77 adolescents) as well as 20-23 (87 students) were examined. The study protocol included the completion of a questionnaire, a breath hydrogen test, as well as the evaluation of the occurrence of intestinal ailments during the test.
\end{abstract}

Results: Hypolactasia was diagnosed in 48 (24\%) subjects, regardless of sex, including $11 \%$ of the children, $22 \%$ of the adolescents, and $31 \%$ of the students ( $p=0.055)$. Lactose intolerance was observed in $65 \%$ of the subjects with hypolactasia, including over $47 \%$ of the adolescents and $85 \%$ of the students.

Conclusions: During BHT, hydrogen concentration in the expired air was the highest in the group of students and the lowest in the children, indicating an age-dependent decline in intestinal lactase activity among people with hypolactasia, which explains the increasing proportions of subjects with lactose intolerance increasing with age.

Key words: hypolactasia, milk intolerance, milk consumption, dairy products consumption.

\section{STRESZCZENIE}

Wstęp: Hypolaktazja u dorosłych jest najczęstszą niealergiczną reakcją niepożądaną na pokarm. Częstość jej wzrasta z wiekiem. Obecność hypolaktazji stwarza ryzyko ograniczania spożycia mleka, co może być przyczyną obniżonej gęstości kości, osteoporozy i złamań.

Celem badań była ocena częstości występowania hypolaktazji wśród mieszkańców Szczecina.

Materiał i metody: Badano 200 losowo dobranych osób w wieku 10-23 lat, które podzielono na 3 grupy wiekowe: 10-14 lat (36 dzieci), 15-19 lat (77 młodzieży) oraz 20-23 lat (87 studentów). Protokół badania obejmował wypełnienie ankiety, wykonanie wodorowego testu oddechowego (WTO) oraz ocenę występowania dolegliwości jelitowych w czasie badania.
Wyniki: Hypolaktazję rozpoznano u 48 (24\%) osób, niezależnie od płci, w tym u 11\% dzieci, u 22\% młodzieży i u 31\% studentów ( $p=0,055)$. Nietolerancję laktozy stwierdzono u $65 \%$ osób z hypolaktazją, w tym $47 \%$ u młodzieży i $85 \%$ u studentów.

Wnioski: W czasie testu WTO stężenia wodoru w powietrzu wydechowym były najwyższe w grupie studentów, a najniższe u dzieci, co wskazywało na obniżanie się z wiekiem aktywności laktazy jelitowej u osób z hypolaktazją, co tłumaczy wzrastający z wiekiem odsetek osób prezentujących objawy nietolerancji laktozy.

Słowa kluczowe: hypolaktazja, nietolerancja mleka, spożycie mleka, spożycie produktów mlecznych.

\section{WSTĘP}

Mleko należy do grupy produktów spożywczych uważanych za najbardziej wartościowe [1]. Dla noworodków i niemowląt jest ono jedynym źródłem pokarmu do czasu wprowadzania do diety posiłków uzupełniających, natomiast osobom dorosłym dostarcza niezbędnych składników odżywczych, głównie białka oraz łatwo przyswajalnego wapnia. Przekrojowe badania amerykańskie wykazały, że mleko i jego produkty są najważniejszym źródłem wapnia, które pokrywa w diecie ok. 83\% jego należnego spożycia wśród dzieci i ok. 70\% wśród osób dorosłych [2].

W Polsce od 1950 r. obserwuje się niskie spożycie mleka i pomimo wyraźnej poprawy jego jakości tendencja ta utrzymuje się nadal. Jedną z przyczyn tego zjawiska może być nietolerancja mleka, będąca następstwem hypolaktazji.

Hypolaktazja to obniżona aktywność laktazy jelitowej, enzymu zlokalizowanego w rąbku szczoteczkowym jelita

\footnotetext{
* Rozprawa na stopień doktora nauk o zdrowiu przyjęta przez Radę Wydziału Nauk o Zdrowiu Pomorskiego Uniwersytetu Medycznego w Szczecinie. Promotor: dr hab. n. med. Grażyna Czaja-Bulsa. Oryginalny maszynopis obejmuje 112 stron, 31 rycin, 28 tabel oraz 180 pozycji piśmiennictwa.
} 
cienkiego i trawiącego cukier mleczny - laktozę [3]. Hypolaktazja występuje u milionów ludzi na całym świecie [4, 5]. W populacjach, w których jest najbardziej rozpowszechniona, poziom laktazy jelitowej obniża się od dzieciństwa do wieku dojrzałego, jednak jej zupełny brak występuje rzadko.

U osób z hypolaktazją poziom laktazy jelitowej jest niższy, zatem trawienie laktozy jest niewystarczające. Doprowadza to do powstania w jelicie grubym węglowodoru, dwutleneku węgla, metanu i wodoru, a w konsekwencji prowadzi do wystąpienia uciążliwych dolegliwości żołądkowo-jelitowych. W przypadkach, gdy u osób z obniżoną aktywnością laktazy jelitowej po spożyciu mleka i jego produktów występują dolegliwości żołądkowo-jelitowe, mówi się o nietolerancji laktozy (NL). Typowymi objawami klinicznymi NL są bóle brzucha, wzdęcie, nudności i biegunka [6]. Występowanie łagodnych objawów NL już w młodym wieku jest prognozą ich zaostrzenia w wieku późniejszym. Wskazane jest wówczas poinformowanie chorych o zawartości laktozy w produktach oraz możliwości dodawania do pokarmu laktazy, aby mogli oni bez dolegliwości spożywać mleko i produkty mleczne zgodnie z aktualnym zapotrzebowaniem organizmu na wapń i inne makro- i mikroelementy [5].

Najczęściej stosowaną metodą pośrednią jest wykonanie wodorowego testu oddechowego (WTO). Obecnie WTO uznawany jest za najlepszą metodę diagnostyczną hypolaktazji $[7,8]$. Wykonywany jest zarówno u dzieci, jak i u dorosłych $[9,10,11,12]$. W badaniu wykorzystywana jest zależność wielkości stężenia wodoru w powietrzu wydychanym od ilości wodoru wytwarzanego w świetle jelit. U osób, które wykazują obniżoną aktywność laktazy, niestrawiona w jelicie cienkim laktoza przechodzi do jelita grubego, gdzie poddawana jest fermentacji bakteryjnej, w wyniku czego powstaje wodór. Związek ten dyfunduje do naczyń krwionośnych, które zaopatrują ścianę jelita, przedostaje się do krążenia i dociera do płuc. W płucach wodór dyfunduje przez barierę włośniczkowo-pęcherzykową do pęcherzyków płucnych. Wykrywa się go w powietrzu wydychanym. Ten proces zachodzi, gdy występuje hypolaktazja oraz obecne są bakterie fermentacyjne w jelicie grubym.

Celem pracy była:

1. Ocena częstości występowania hypolaktazji mierzonej wodorowym testem oddechowym wśród dzieci, młodzieży i studentów ze Szczecina.

2. Ocena rodzaju, częstości i czasu występowania dolegliwości jelitowych po spożyciu laktozy u osób z hypolaktazją.

3. Ankietowa ocena częstości spożycia mleka i produktów mlecznych przez dzieci, młodzież i studentów ze Szczecina.

4. Ankietowa ocena częstości, rodzaju i czasu występowania dolegliwości po spożyciu mleka i produktów mlecznych przez dzieci, młodzież i studentów ze Szczecina.

5. Ocena wpływu występowania hypolaktazji na wielkość spożycia mleka i produktów mlecznych przez dzieci, młodzież i studentów ze Szczecina.

6. Ocena częstości występowania hypolaktazji w stosunku do przekonania badanych o występowaniu u nich dolegliwości jelitowych po spożyciu mleka i jego przetworów.

\section{MATERIA $\longleftarrow$ I METODY}

Grupę badaną stanowiło 200 osób, 156 dziewcząt i 44 chłopców w wieku 10-23 lat (średnia 18 lat). Podzielono ich na 3 grupy wiekowe: grupa I - 36 dzieci w wieku 10-14 lat, grupa II - 77 młodzieży w wieku 15-19 lat i grupa III - 87 studentów w wieku 20-23 lat - odpowiednio: 18\%, 38,5\% i 43,5\%.

Kryteriami włączenia osób do grupy badanej był wiek i wyrażenie zgody na udział w badaniu. Kryteriami wyłączenia z badań było występowanie znanych chorób przewodu pokarmowego, dla których dane z piśmiennictwa wskazują na częste występowanie hypolaktazji: alergia pokarmowa, w tym alergia na mleko krowie, nieswoiste zapalenie jelit, celiakia, mukowiscydoza, zaburzenia gospodarki węglowodanowej lub występowanie chorób metabolicznych. Pacjenci nie mogli również w czasie badania zażywać żadnych leków ani przyjmować antybiotyków przez ostatnie 4 tygodnie.

Protokół badania składał się z 3 elementów. Należało wypełnić ankietę, wykonać WTO oraz ocenić dolegliwości występujące u pacjentów w czasie WTO.

Kwestionariusz autorskiej ankiety składał się z 11 pytań. Dotyczył on ilości i częstości spożywanego mleka oraz produktów mlecznych, a także dolegliwości, które występują u osób po ich spożyciu. Pacjenci wypełniali ankietę bezpośrednio przed wykonaniem WTO.

Wodorowy test oddechowy wykonywano za pomocą aparatu Gastrolyzer firmy Bedfont. Pierwszy pomiar stężenia wodoru w powietrzu wydychanym mierzono na czczo. Następne oznaczenia wykonywano po 15, 30, 60 i 90 min od wypicia przez badanego wodnego roztworu laktozy. Laktozę podawano w dawce $2 \mathrm{~g} / \mathrm{kg}$ masy ciała (maksymalnie 50 g laktozy rozpuszczonej w ok. 400 mL wody). Hypolaktazję rozpoznawano, gdy wartość stężenia wodoru w wydychanym powietrzu wynosiła co najmniej 20 ppm (parts per milion - ilość cząstek analizowanego gazu na milion cząstek powietrza). Badanie wykonywano po 12 godz. nieprzyjmowania przez pacjenta żadnych posiłków ani leków. Antybiotyki mogły być zażywane co najmniej 4 tygodnie wcześniej.

W czasie wykonywania WTO zapisywano czas oraz rodzaj zgłaszanych przez pacjenta dolegliwości jelitowych (bóle brzucha, wzdęcie, nudności i luźne stolce).

Badanie przeprowadzono w latach 2010-2011 w szczecińskich szkołach, na uczelniach oraz w gabinetach podstawowej opieki zdrowotnej po wcześniejszym poinformowaniu dzieci, młodzieży i studentów o jego celu i metodzie wykonania. Od każdego badanego oraz jego rodzica (lub opiekuna prawnego) uzyskano pisemną zgodę na wykonanie badania jeszcze przed jego rozpoczęciem.

Wszystkie uzyskane dane zarchiwizowano w postaci elektronicznej w bazie danych programu Excel i poddano opracowaniu statystycznemu. Normalność rozkładów zmiennych ciągłych sprawdzono testem Kołmogorowa-Smirnowa. Opisano je za pomocą średnich, odchylenia standardowego, wartości minimalnej i maksymalnej. Różnice statystyczne między badanymi grupami obliczano testem t-Studenta. Zmienne nieciągłe opisano przez ilość i częstość występowania. Do badania 
statystycznych zależności pomiędzy zmiennymi nieciągłymi zastosowano test $\chi^{2}$ Pearsona lub R rang Spearmana.

Za różnice istotne statystycznie we wszystkich przeprowadzonych testach uznano te, dla których prawdopodobieństwo (p) było niższe od 0,05.

\section{WYNIKI}

W badanej grupie hypolaktazję rozpoznano u 48 (24\%) osób, częściej w grupie studentów (31\%) niż młodzieży (22\%) i dzieci (11\%; p = 0,055) - rycina 1.

W grupie 48 osób z hypolaktazją w czasie wykonywania WTO reakcje niepożądane po spożyciu laktozy zgłaszało 31 (65\%) z nich. Były to osoby w wieku 15-19 lat (47\%) i starsze (85\%). Dolegliwości nie zgłaszało żadne dziecko z grupy najmłodszej. Zarówno wśród młodzieży, jak i studentów z czasem trwania badania wzrastała liczba osób z dolegliwościami. Wśród młodzieży w kolejnych okresach badania (30, 60 i 90 min) ulegała ona zdwojeniu: 12\%, 23\% i 47\%. U studentów wzrastała szybciej: $4 \%$ w 15 . min badania, $11 \%$ w $30 . \min , 63 \% \mathrm{w} 60 . \mathrm{min}$ oraz $85 \%$ w 90. min (ryc. 2).

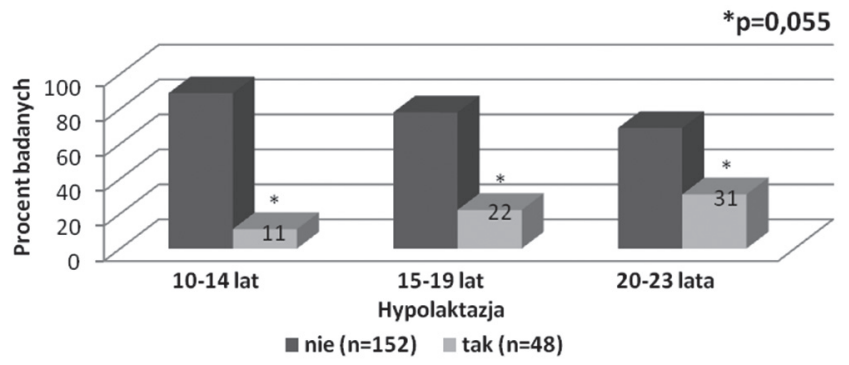

RYCINA 1. Częstość występowania hypolaktazji ocenianej wodorowym testem oddechowym w badanej grupie osób

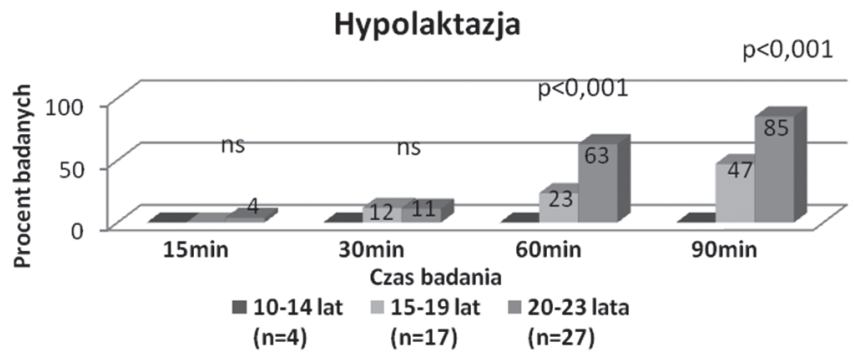

RYCINA 2. Czas występowania reakcji niepożądanych po spożyciu laktozy w czasie wodorowego testu oddechowego u osób z hypolaktazją w zależności od wieku badanych

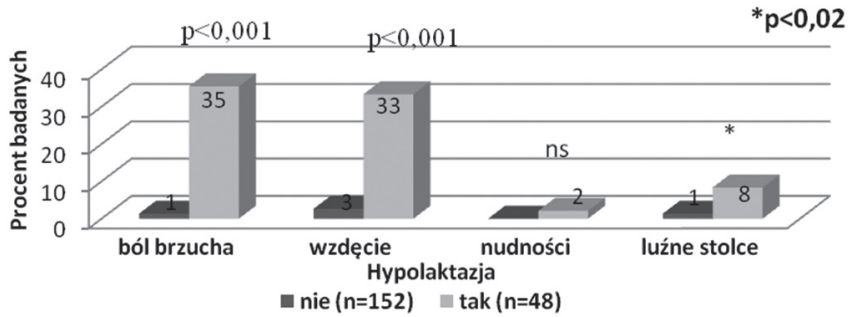

RYCINA 3. Rodzaj reakcji niepożądanych występujących w 90. minucie wodorowego testu oddechowego w badanej grupie osób

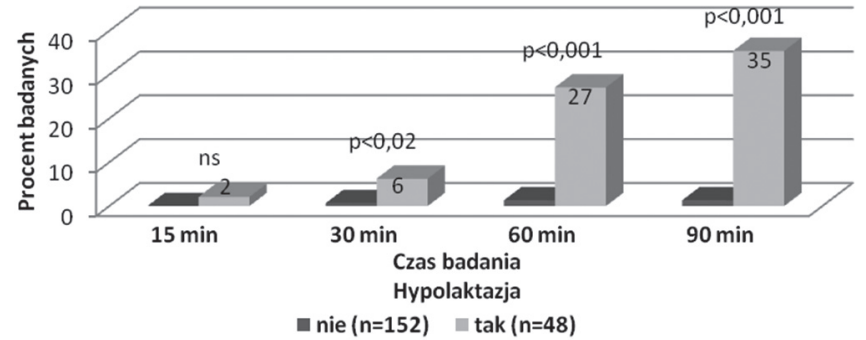

RYCINA 4. Częstość i czas występowania bólu brzucha po spożyciu laktozy w czasie wodorowego testu oddechowego w badanej grupie osób

Hypolaktazja $(n=48)$

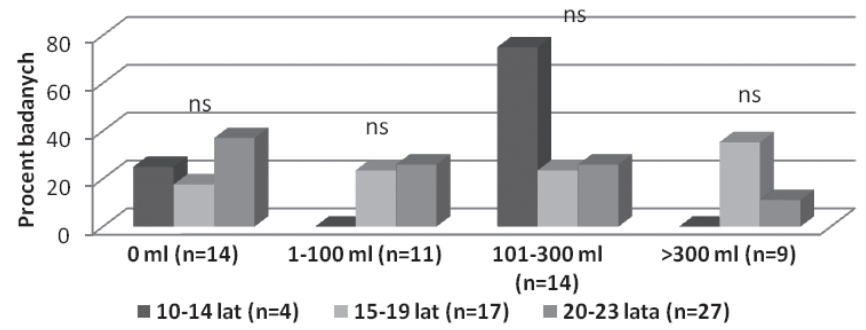

RYCINA 5. Wielkość dziennego spożycia mleka przez osoby z hypolaktazją w zależności od wieku

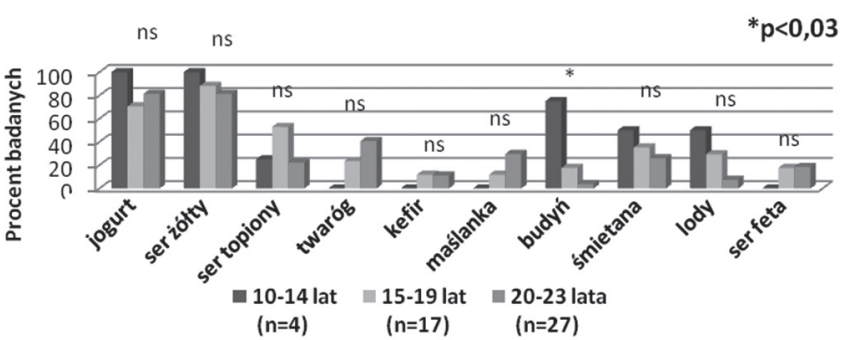

RYCINA 6. Dzienne spożycie produktów mlecznych przez osoby z hypolaktazją w zależności od wieku

Po spożyciu laktozy w trakcie WTO najczęściej obserwowano bóle brzucha i wzdęcie (19\% i 16\%), natomiast biegunka i nudności występowały rzadko (4\% i 2\%). U dzieci z hypolaktazją częstość reakcji niepożądanych była istotnie wyższa; zgłaszało je 31 dzieci (ryc. 3).

U pacjentów z hypolaktazją częstość występowania bólu brzucha wzrastała z czasem trwania badania. W 15. min zgłaszało go 1 (2\%) dziecko, w 30. min 3 (6\%) dzieci, w 60. min 13 (27\%) dzieci, a w 90. $\min 17$ (35\%) dzieci - rycina 4.

Mleko piło $71 \%$ badanych z hypolaktazją (75\% dzieci, $82 \%$ młodzieży, $63 \%$ studentów) oraz $72 \%$ bez hypolaktazji $(81 \%$ dzieci, 73\% młodzieży, 67\% studentów), co jest nieistotne statystycznie (NS). W żadnej z grup wiekowych ilość spożywanego mleka nie różniła się istotnie pomiędzy osobami z hypolaktazją i bez hypolaktazji (ryc. 5).

W grupie osób z hypolaktazją 29\% nie piło mleka (25\% dzieci, $18 \%$ młodzieży i $37 \%$ studentów), $23 \%$ piło do $100 \mathrm{~mL}$ dziennie (23\% młodzieży, 26\% studentów), a kolejne 29\% spożywało 101-300 mL (75\% dzieci, 23\% młodzieży, 26\% studentów). Więcej niż $300 \mathrm{~mL}$ mleka wypijało 19\% badanych (35\% młodzieży i $11 \%$ studentów) - rycina 5. 
Wśród osób z hypolaktazją dzieci piły 101-300 mL mleka dziennie, młodzież więcej niż $300 \mathrm{~mL}$ mleka, a studenci najczęściej nie spożywali go w ogóle (ryc. 6).

Z produktów mlecznych badani najczęściej spożywali jogurt (81\%), ser żółty (78\%) i ser biały (44\%). Ser żółty codziennie jadło $85 \%$ badanych z hypolaktazją (100\% dzieci, $88 \%$ młodzieży i $81 \%$ studentów) oraz $76 \%$ osób bez hypolaktazji (59\% dzieci, $75 \%$ młodzieży i 87\% studentów) - NS. Jogurt codziennie spożywało 79\% osób z hypolaktazją (100\% dzieci, 71\% młodzieży i $81 \%$ studentów) oraz $82 \%$ bez hypolaktazji ( $81 \%$ dzieci, $75 \%$ młodzieży i 90\% studentów) - NS. Ser biały codziennie jadło $35 \%$ badanych z hypolaktazją (23\% młodzieży i 41\% studentów) oraz $48 \%$ bez hypolaktazji ( $31 \%$ dzieci, $47 \%$ młodzieży i 58\% studentów) - NS (ryc. 6). Różnice istotne statystycznie w wielkości spożycia produktów mlecznych pomiędzy osobami z hypolaktazją i bez hypolaktazji stwierdzono tylko w grupie dzieci dla budyniu (22\% vs 75\%; p = 0,025).

\section{DYSKUSJA}

W przedstawionym materiale hypolaktazję rozpoznano u 48 (24\%) osób, w tym 11\% u dzieci w wieku 10-14 lat, 22\% u młodzieży w wieku 15-19 lat oraz 31\% u studentów w wieku 20-23 lat. Podobne wyniki przedstawili inni badacze z różnych regionów Polski. Szostak-Węgierek i Szostak potwierdzili obecność hypolaktazji u 19\% warszawskich dzieci w wieku 7-15 lat [13]. Kwiecień $i$ wsp. hypolaktazję wykazali u 17,4 dzieci w wieku 8-11 lat z terenu Zabrza [14]. Natomiast Socha $i$ wsp. badając młodzież i młodych dorosłych, stwierdzili ją u 37,5\% $\mathrm{z}$ nich, a Fojcik $i$ wsp. na podstawie testów genetycznych - u 31\% osób $[15,16]$.

Częstość, z jaką występuje hypolaktazja w Polsce, jest zbliżona do innych krajów Europy Środkowej. W Niemczech jej rozpowszechnienie szacuje się na 6-23\%, w Austrii i Hiszpanii na 5-28\%, a w północnej Francji na 23\% [17]. W Estonii hypolaktazję stwierdza się u 31\% osób [16, 18, 19]. Na południu Europy częstość występowania hypolaktazji jest wyższa, a na północy niższa. Na południu Francji hypolaktazję rozpoznaje się u 50\% osób, podobnie w północnych Włoszech (51\%), częściej na Sycylii (70\%), w Neapolu (80\%) i Grecji (45-75\%). W Norwegii, Szwecji i Danii hypolaktazja występuje wśród 1-7\% populacji, w Wielkiej Brytanii i Irlandii u 4-5\% [17]. W populacji fińskiej dotyczy $17 \%$ ludzi, natomiast wśród ludności zamieszkującej Cejlon rozpoznaje się ją u 34\% [20].

Częstość występowania hypolaktazji typu dorosłego wzrasta z wiekiem. W grupie osób zamieszkujących Szczecin hypolaktazję stwierdzono u 11\% dzieci w wieku 10-14 lat. W ciągu każdych kolejnych 5 lat stwierdzano wzrost częstości hypolaktazji o 10\%, tak więc w wieku 15-19 lat częstość hypolaktazji wynosiła $22 \%$, a w wieku 20-23 lata 31\%. Proces ten przebiega odmiennie w innych populacjach. W populacji chińskiej szybki wzrost częstości hypolaktazji Tadesse i wsp. obserwowali dopiero pomiędzy 14. a 15. r.ż. [21]. Sahi i wsp. badając populację fińską, stwierdzili szybki wzrost częstości hypolaktazji pomiędzy 10. a 20. r.ż. [18].
W analizowanym materiale nie wykazano zależności pomiędzy częstością występowania hypolaktazji a płcią badanych. Podobne wyniki uzyskali Szostak-Węgierek i Szostak, Landowski i wsp. oraz Socha i wsp. [13, 22, 23, 24].

W badanej grupie reakcje niepożądane po spożyciu wodnego roztworu laktozy zgłosiło 65\% osób z hypolaktazją. Liczba zgłaszających dolegliwości jelitowe wzrastała wraz z wiekiem badanych. Najczęściej podawali je studenci (85\%), rzadziej młodzież (47\%), natomiast nie zgłosiło ich żadne dziecko z grupy najmłodszej, co wskazuje, że stopień obniżenia aktywności laktazy jelitowej był najwyższy u studentów, a najniższy u dzieci. Obserwacja ta jest zgodna z mechanizmem obniżania się aktywności laktazy jelitowej u ludzi z dorosłym typem hypolaktazji. Od wystąpienia tego procesu obserwuje się nie tylko spadek liczby osób z prawidłową aktywnością enzymu, ale również systematyczny spadek aktywności enzymu u osób z hypolaktazją, u których w kolejnych latach maleje tolerancja laktozy.

Niniejsza sytuacja potwierdza też znany fakt, że hypolaktazja występuje częściej niż klinicznie jawna nietolerancja laktozy. U osób z hypolaktazją objawy po spożyciu cukru mlecznego najczęściej mają charakter indywidualny i łagodny, mogą jednak zaostrzyć się po spożyciu jego dużej dawki. Na stopień demonstrowanych dolegliwości ma wpływ wiele czynników, m.in.: wiek, aktywność laktazy w jelicie cienkim, szybkość opróżniania żołądkowego i pasaż przez jelita oraz rodzaj flory występującej w jelicie grubym. Istnieje indywidualna reakcja osób z hypolaktazją na przyjętą dawkę laktozy [14, 25, 26].

Kwiecień $i$ wsp. wykonując wodorowy test oddechowy u dzieci w wieku szkolnym, stwierdzili, że pomimo obciążenia ich dużą dawką laktozy, odpowiadającą ok. 1 L mleka krowiego, dolegliwości zgłaszało tylko $18 \%$ osób z poziomem wodoru w wydychanym powietrzu ponad 20 ppm [14]. Szostak-Węgierek i Szostak obciążając dzieci warszawskie taką samą dawką laktozy, stwierdzili objawy jej nietolerancji u jeszcze mniejszego odsetka - u 14\% [13]. Natomiast Carrocio i wsp. podając tylko $25 \mathrm{~g}$ laktozy dorosłym mieszkańcom Sycylii, wykazał podwyższony poziom wodoru u 32\% badanych, ale jawne objawy nietolerancji laktozy tylko u 12\% osób z hypolaktazją [26]. Jackson i Latham badając masajskie dzieci w Afryce Wschodniej, wykazali, że pomimo hypolaktazji i wysokiego spożycia mleka, co jest zjawiskiem powszechnym, dolegliwości ze strony przewodu pokarmowego po spożyciu mleka występują u nich rzadko [27]. Podobne wyniki uzyskał Flatz $i$ wsp., wykonując WTO u 118 pasterzy koczujących na Saharze [28]. Tadesse i wsp., którzy badali nietolerancję laktozy w populacji chińskiej (8.-18. r.ż.), stwierdzili, że wszystkie osoby z hypolaktazją tolerowały mleko $\mathrm{w}$ dawce $5 \mathrm{~mL} / \mathrm{kg}$ m.c. (co odpowiada $0,25 \mathrm{~g}$ laktozy/kg masy ciała) [21].

W wielu badaniach wykazano, że osoby z nietolerancją laktozy (NL) tolerują 10-18 g laktozy, najczęściej 12 g, co odpowiada jednej filiżance mleka - $250 \mathrm{~mL}$, zwłaszcza jeśli jest spożywana z innymi pokarmami [8, 26, 29]. Po 10-15 g laktozy dolegliwości jelitowe zgłasza tylko 30-60\% badanych [30]. Uważa się, że objawy NL stają się widoczne, gdy osoba z hypolaktazją spożyje więcej niż $12 \mathrm{~g}$ laktozy i silniejsze po spożyciu $24 \mathrm{~g}$ laktozy. Wypicie $50 \mathrm{~g}$ laktozy powinno wyzwalać objawy 
NL u 70-90\% osób z hypolaktazją [26, 30]. W opisywanej populacji szczecińskiej podaż 50 g laktozy w roztworze wodnym wyzwalała objawy niepożądane u 65\% osób z hypolaktazją. Były to tylko osoby starsze, młodzież w wieku 15-19 lat oraz studenci. Nie stwierdzono objawów niepożądanych u żadnego dziecka w wieku 10-14 lat z hypolaktazją. Istotną trudnością w ocenie tej sytuacji jest fakt, że w grupie dzieci hypolaktazję wykazano u małej liczby osób - tylko u 4 dzieci.

U osób z nietolerancją laktozy dolegliwości jelitowe występują w krótkim czasie po spożyciu laktozy. W przeprowadzonych badaniach populacji szczecińskiej obserwowano je do 90 min od spożycia laktozy, najczęściej w 60 min (44\% osób) i 90 min (65\% osób). Podobne wyniki przedstawili inni autorzy [4]. Badani najczęściej skarżyli się na ból brzucha (35\%) i wzdęcie (33\%), natomiast luźne stolce oraz nudności występowały znacznie rzadziej ( $8 \%$ i 2\%). Podobne wyniki przedstawili Małecka i wsp., którzy badali dzieci do 18. r.ż. [31]. Mądry i wsp., którzy podawali młodym dorosłym (20-25 lat) $400 \mathrm{~mL}$ mleka, jogurtu i kefiru, również najczęściej jako reakcję niepożądaną obserwowali bóle brzucha [32].

W badanej grupie osób hypolaktazję rozpoznano u 48 (24\%) osób. Obecność jej nie wpływała na wielkość spożycia mleka i jego produktów. Podobne wyniki uzyskali Esterle i wsp., badając we Francji 192 dziewczynki w wieku 12-22 lat oraz Hutyra i Iwańczak, przeprowadzając badania wśród dzieci i młodzieży z chorobami przewodu pokarmowego, którzy byli hospitalizowani w Klinice Pediatrii, Gastroenterologii i Żywienia Akademii Medycznej we Wrocławiu [33, 34].

W analizowanej grupie osób spożycie mleka i jego produktów ograniczały 23 osoby (11\%), istotnie częściej dzieci - 28\% niż młodzież i studenci - po 8\%. Ograniczenia stosowało $10 \%$ badanych bez hypolaktazji i 17\% z hypolaktazją: w grupie najmłodszej - 28\% dzieci bez hypolaktazji i 25\% z hypolaktazją, a wśród młodzieży $7 \%$ bez hypolaktazji i 12\% z hypolaktazją. Istotne różnice dotyczyły studentów - 3\% bez hypolaktazji i 18\% z hypolaktazją. Zatem w grupie badanej co 10. osoba bez hypolaktazji ograniczała spożycie mleka i produktów mlecznych, mimo że nie miała żadnej reakcji niepożądanej (ani alergii na mleko, ani hypolaktazji). Ograniczanie spożycia było zatem następstwem preferencji żywieniowych. Takie postępowanie najczęściej obserwowano wśród najmłodszych, tzn. w grupie dzieci w wieku 10-14 lat, i dotyczyło ono 28\% badanych. Rzadziej stwierdzano je wśród młodzieży - 7\%, najrzadziej w grupie studentów - 3\%.

Wśród osób z hypolaktazją ograniczenie spożycia mleka i jego produktów częściej stosowali studenci niż młodzież (17\% vs 12\%). W grupie dzieci w wieku 10-14 lat spożycie mleka ograniczała jedna z czterech osób z hypolaktazją. Wielkość i częstość spożycia mleka była taka sama u osób z hypolaktazją i bez hypolaktazji.

Ser żółty, jogurt i ser biały, w przeciwieństwie do mleka, bez ograniczeń są tolerowane przez osoby z hypolaktazją. W jogurcie zawarte są bakterie uwalniające laktazę, która wspomaga trawienie cukru mlecznego. W białym serze ilość laktozy jest 2-3-krotnie mniejsza. Stosowanie takich upodobań w doborze produktów mlecznych powoduje, że osoby z hypolaktazją nie mają poczucia stosowania ograniczeń dietetycznych, a w rzeczywistości stosują dietę niskolaktozową. Dlatego, pomimo że mają oni obniżoną aktywność laktazy jelitowej, nie występują u nich żadne dolegliwości.

Tylko niewielka liczba osób z grupy młodzieży i studentów podała, że musi ograniczać spożycie mleka i nabiału (po 8\%), podczas gdy hypolaktazja występowała wśród nich znacznie częściej (22\% i 31\%). W całej badanej grupie oraz niezależnie w grupie dzieci i młodzieży nie stwierdzono różnic istotnych statystycznie w ograniczaniu spożycia mleka, a także produktów mlecznych pomiędzy osobami z obniżoną i prawidłową aktywnością laktazy jelitowej. Różnicę taką wykazano tylko dla grupy studentów (18\% vs 3\%).

Ograniczenia w spożyciu mleka i produktów mlecznych w grupie badanej najczęściej stwierdzano wśród najmłodszych dzieci w wieku 10-14 lat. Nietolerancję laktozy rozpoznano tylko u $11 \%$ z nich, a ograniczenia spożycia mleka i nabiału stosowało aż 28\%. U żadnego dziecka nie potwierdzono także innej choroby wymagającej eliminacji mleka. Nie jesteśmy w stanie ocenić, czy było to następstwem ich upodobań żywieniowych, czy przekonań opiekunów. Eggesbø i wsp. oceniając częstość występowania reakcji niepożądanych na mleko i jaja wśród 2721 dzieci w wieku 2,5 lat, wykazali, że u 1/3 z nich rodzice stosują ścisłą dietę dotyczącą spożycia tych pokarmów, w tym u 1/6 rozpoczynają rygorystyczną dietę bez konsultacji z lekarzem. Stosowanie takiej diety eliminacyjnej w znacznej części jest nieuzasadnione [35, 36]. Niski odsetek weryfikacji zasadności eliminacji pokarmu z diety potwierdzili także Caffarelli i wsp., badając włoskie dzieci w wieku szkolnym [37]. Dietę eliminacyjną stosowało 10\% dzieci, a tylko co 13. uczeń był z tego powodu diagnozowany. Jeszcze wyższy odsetek zdrowych dzieci w wieku 1-9 lat, leczonych dietą eliminacyjną stwierdzili Fleischer i wsp.; dla różnych pokarmów wynosił on 84-93\% [38].

Ograniczenie spożycia mleka i jego produktów prowadzi do niedoborów wapnia w organizmie i obniżonego uwapnienia kości. Infante i Tormo badając dzieci z nietolerancją laktozy typu dorosłych u 20\% z nich, wykazali cechy osteoporozy [39]. Segal i wsp. u 17\% badanych z NL stwierdzili podwyższony poziom parathormonu, co jest następstwem wtórnej nadczynności przytarczyc [40].

Istotnym jest, aby osoby z hypolaktazją nie eliminowały z diety mleka i jego produktów. W 55 badaniach obejmujących 223 tys. osób udowodniono, że niskie spożycie mleka zwiększa ryzyko złamań kości. Osoby z nietolerancją mleka powinny tylko ograniczać na dany posiłek mleko oraz wybierać te produkty mleczne, które zawierają mniejszą ilość laktozy. Z wyników badań wiadomo, że u większości osób nie występują objawy, gdy spożywają one do 12 g laktozy [26]. Oznacza to, że jednorazowo można wypić do 1 szklanki mleka. Pacjenci mogą spożywać większe ilości produktów niskolaktozowych, tj.: mleka niskolaktozowego, jogurtów, serów żółtych i topionych. Codziennie powinni spożywać taką ilość mleka i produktów mlecznych, aby zabezpieczyć dla organizmu prawidłowy poziom wapnia. Jeśli jest niewystarczający, muszą codziennie spożywać preparaty wapnia [41]. Nie ma wystarczającej ilości badań, aby stwierdzić, że dodawanie probiotyków do diety zwiększa tolerancję laktozy [26]. 


\section{WNIOSKI}

1. Częstość występowania hypolaktazji ocenianej wodorowym testem oddechowym wśród dzieci, młodzieży oraz studentów ze Szczecina wzrasta z wiekiem i jest taka sama, jak na innych obszarach Polski i Europy Środkowej.

2. U osób $z$ hypolaktazją podaż wodnego roztworu laktozy (2 g laktozy na kg masy ciała; maks. 50 g) w 60. i 90. min od spożycia może prowadzić do wystąpienia reakcji niepożądanych, najczęściej bólów brzucha i/lub wzdęcia, rzadko nudności oraz luźnych stolców. Odsetek osób z hypolaktazją, u których występują dolegliwości, wzrasta z wiekiem; stwierdza się je u połowy młodzieży i większości studentów.

3. Wśród osób w wieku 10-23 lat zamieszkujących Szczecin najczęściej spożywanymi produktami mlecznymi są jogurt i ser żółty. Większość dzieci i młodzieży oraz 1/3 studentów pije także codziennie co najmniej połowę szklanki mleka.

4. Co czwarta mieszkająca w Szczecinie osoba w wieku 10-23 lat uważa, że spożycie mleka i jego produktów, najczęściej w czasie pierwszej godziny od posiłku, wywołuje u niej reakcje niepożądane pod postacią bólów brzucha, rzadziej wzdęcia, nadmiernego oddawania gazów, luźnych stolców lub wymiotów. Odsetek osób, które mają to przekonanie, maleje wraz z wiekiem.

5. Występowanie hypolaktazji nie wpływa na wielkość i częstość spożycia mleka oraz produktów mlecznych. Głównym czynnikiem determinującym niskie spożycie mleka i wysokie niskolaktozowych produktów mlecznych są preferencje żywieniowe badanych.

6. Większość osób przekonanych, że spożycie mleka i jego produktów wyzwala u nich jelitowe reakcje niepożądane, nie ma żadnych dolegliwości po spożyciu laktozy, czyli nie ma hypolaktazji. Równocześnie tylko co 5. osoba z hypolaktazją uważa, że ma dolegliwości jelitowe po spożyciu mleka i jego produktów. Tymczasem u młodzieży i studentów z hypolaktazją występują one 2-3-krotnie częściej.

\section{PIŚMIENNICTWO}

1. Haug A., Hostmark A.T., Harstad O.M.: Bovine milk human nutrition - a review. Lipids Health Dis. 2007, 6, 25.

2. Huth P.J., DiRienzo D.B., Miller G.D.: Major scientific advances with dairy foods in nutrition and health. J Dairy Sci. 2006, 89, 1207-1221.

3. Fidler E., Lisowska A., Walkowiak J.: Nietolerancja laktozy - klasyfikacja i diagnostyka. Pediatr Pol. 2009, 6, 562-566.

4. Escher J.C., Büller H.A.: Nietolerancja laktozy. Wyd. Czelej, Katowice 2006 , 62, 407-409.

5. Szostak W., Szostak D.: Hipolaktazja. Niedoceniony problem kliniczny o dużym znaczeniu dla zdrowia publicznego. Prz Pediat. 1997, 27, 181-182.

6. Hutyra T., Iwańczak B.: Nietolerancja laktozy: patofizjologia, objawy kliniczne, rozpoznanie i leczenie. Pol Merkur Lekarski. 2009, 26, 148-152.

7. Heyman M.B., Committee on Nutrition: Lactose intolerance in infants, children and adolescents. Pediatrics. 2006, 118, 1279-1286.

8. Usai-Satta P., Scarpa M., Oppia F., Cabras F.: Lactose malabsorption and intolerance: What should be the best clinical management? Word J Gastrointest Pharmacol Ther. 2012, 6, 29-33.

9. Landowski P., Kamińska B., Szumera M., Brodzicki J., Radys W., Korzon M.: Ocena bakteryjnych procesów fermentacyjnych zachodzących w jelicie grubym dzieci z wybranymi schorzeniami przewodu pokarmowego. Prz Gastroenterol. 2007, 2, 38-41.

10. Lember M.: Assesment of lactose tests. Am Fam Physician. 2002, 66, 2206-2208.

11. Michalczuk M., Sybilski A.J.: Nietolerancje pokarmowe. Pediatr Med Rodz. 2010, 3, 189-193.

12. Rujner J.: Nietolerancja laktozy (cukru mlekowego) i galaktozy. In: Dieta bezglutenowa i bezmleczna dla dzieci i dorosłych. Eds: J. Rujner, B. Cichańska. Wyd. Lek. PZWL, Warszawa 2002, 2, 23-28.

13. Szostak-Węgierek D., Szostak W.B.: Występowanie hipolaktazji u dzieci w wieku szkolnym w Warszawie. Pediatr Pol. 1999, 74, 13-17.

14. Kwiecień J., Szadkowski L., Szostak W., Żabka A., Karczewska K., Kasner J.: Hipolaktazja u dzieci szkolnych z terenu miasta Zabrza. Pediatr Współcz Gastroenterol Hepatol Żyw Dzieci. 2005, 7, 15-18.

15. Fojcik H., Moczulski D., Gawlik B., Grzeszczak W.: The frequency of primary $\mathrm{Li}$ in Polish population based on genetic testing. Gastroenterol Pol. 2006, 13, 81-83.

16. Guzek M., Stojek M., Wypych J., Pawłowska A., Sulkowska A., Smoczyński M.: Nietolerancja laktozy u osób z niespecyficznymi dolegliwościami żołądkowo-jelitowymi. Gastroenterol Pol. 2007, 14, 17-20.

17. Sahi T.: Genetics and epidemiology of adult - type hypolactasia. Scand J Gastroenterol. 1994, 29, 7-20.

18. Sahi T., Launiala $K$., Laitinen $H .:$ Hypolactasia in a fixed cohort of young Finnish adults. A follow-up study. Scand J Gastroenterol. 1983, 18, 865-870.

19. Tammur R.: Lactose malabsorption among the patients with non-specific abdominal complaints. Acta Comment Univ Tartu. 1987, 790, 68-72.

20. Senewiratne B., Thambipillai S., Perera H.: Intestinal lactase deficiency in Ceylon (Sri Lanca). Gastroenterology. 1977, 72, 1257-1259.

21. Tadesse K., Yuen R.C., Leung D.T.: Late-onset hypolactasia in Hong Kong school children. Ann Trop Paediatr. 1991, 11, 289-292.

22. Landowski P.: Występowanie nietolerancji laktozy u dzieci i młodzieży i jej wpływ na stan zdrowia i rozwój fizyczny. Praca doktorska. Akad. Med. w Gdańsku, Gdańsk 2002.

23. Socha J., Książyk J., Flatz G., Flatz S.G.: Prevalence of primary adult lactose malabsorption in Poland. Ann Hum Biol. 1984, 11, 311-316.

24. Newcomer A.D., McGill D.B.: Clinical importance of lactase deficiency. N Eng J Med. 1984, 310, 42-43.

25. Wilt T.J., Shaukat A., Shamliyan T., Taylor B.C., MacDonald R., Tacklind J. et al:: Lactose intolerance and health. Evid Rep Technol Assess (Full Rep.) 2010, 192, 1-410.

26. Carrocio A., Montalto G., Cavera G., Notarbatolo A.: Lactose intolerance and-self reported milk intolerance: relatlonshi with lactose maldigestion and nutrient intake. Lactase Deficiency Study Groupe. J Am Coll Nutr. 1998, 17, 631-636.

27. Jackson R.T., Latham M.C.: Lactose malabsorption among Masai children of East Africa. Am J Clin Nutr. 1979, 32, 779-782.

28. Flatz G., Schildge C., Sekou H.: Distribution of adult lactase phenotypes in the Tuareg of Niger. Am J Hum Genet. 1986, 38, 515-520.

29. Shaukat A., Levitt M.D., Taylor B.C., MacDonald R., Shamliyan T.A., Kane R.L. et al: Systematic review: effective management strategies for lactose intolerance. Ann Intern Med. 2010, 152, 797-803.

30. Auricchio S., Trancone R.: Genetically determined disccharidase deficiency. In: Pediatric gastrointestinal disease. Eds: W.A. Walker, P.R. Durie, J.R. Hamilton, J.A. Walker-Smith, J.B. Watkins. BC Decker, Ontario 2000, 677-700.

31. Małecka M., Bobrus M., Kosielska J., Czkwianianc E.: The analysis of incidence of the most common clinical symptoms and comorbidity in children with lactose intolerance conducted on the basis of own material. Gastroenterol Pol. 2010, 6, 397-400.

32. Mądry E., Krasińska B., Woźniewicz M., Drzymała-Czyż S., Bobkowski W., Torlińska T. et.al.: Tolerance of different dairy products in subjects with symptomatic lactose malabsorption due to adult type hypolactasia. Prz Gastroenterol. 2011, 5, 310-315.

33. Esterle L., Sabatier J.P., Guillon-Metz F., Walrant-Debray O., Guaydier-Souquieres G., Jehan F. et al:: Milk, rather than other foods, is associated with vertebral bone mass and circulating IGF-1 in female adolescents. Osteoporos Int. 2009, 4, 567-575.

34. Hutyra T., Iwańczak B.: Ocena spożycia mleka oraz produktów mlecznych i jego związku z upośledzonym trawieniem i wchłanianiem laktozy lub nietolerancją laktozy w niektórych chorobach przewodu pokarmowego u dzieci. Pol Merkur Lekarski. 2009, 152, 110-116. 
35. Eggesbø M., Botten G., Stigum H.: Restricted diets in children with reactions to milk and egg perceived by their parents. J Pediatr. 2001, 139, 583-587.

36. Eggesbø M., Botter G., Halvorsen R., Magnus P.: The prevalence of allergy to egg: a population-based study in young children. Allergy. 2001, 56, 403-411.

37. Caffarelli C., Coscia A., Ridolo E., Povesi Dascola C., Gelmetti C., Raggi V. et al.: Parent's estimate of food allergy prevalence and management in Italian school-aged children. Pediatr Int. 2011, 4, 505-510.

38. Fleischer D.M., Bock S.A., Spears G.C., Miyazawa N.K., Gleason M.C., Gyorkos E.A. et al.: Oral food challenges in children with a diagnosis of food allergy. J Pediatr. 2011, 4, 578-583.
39. Infante D., Tormo R.: Risk of inadequate bone mineralization in diseases involving long-term suppression of dairy products. J Pediatr Gastroenterol Nutr. 2000, 30, 310-313.

40. Segal E., Dvorkin L., Lavy A., Rozen G.S., Yaniv I., Raz B. et al.: Bone density in axial and appendicular skeleton in patients with lactose intolerance: influence of calcium intake and vitamin D status. J Am Coll Nutr. 2003 22, 201-207.

41. Montalto M., Gallo A., Santoro L.D., D'Onofrio F., Curigliano V., Cammarota G. et al: Low-dose lactose in drugs neither increases breath hydrogen excretion nor causes gastrointestinal symptoms. Aliment Pharmacol Ther. 2008, 28, 1003-1012. 